\title{
Enhancing Classification Skills Using i-Bird Apps in Zoology Vertebrata Course
}

\author{
https://doi.org/10.3991/ijet.v15i17.13561 \\ Iwan Setia Kurniawan $(\bowtie)$ \\ Universitas Pasundan, Bandung, Indonesia \\ iwansetiakurniawan@unpas.ac.id \\ Fransisca Sudargo Tapilouw, Topik Hidayat, Wawan Setiawan \\ Universitas Pendidikan Indonesia, Bandung, Indonesia
}

\begin{abstract}
Smartphone applications are developing so rapidly with increasingly sophisticated features. However, smartphone applications widely used to fulfill social needs rather than being used to support learning. The classification skills are essential possessed by students to facilitate the learning of various species. By integrating technology, students expected to be able to have good classification skills. This study aims to improve the classification ability of prospective biology teacher students by using the i-Bird application in the Zoology Vertebrate course. The i-Bird application designed and created specifically for studying Aves. This study uses a quasi-experimental method with a randomized control group pretest and posttest design. Involving 82 students divided into two groups. 44 students as an experimental class using the i-Bird app on smartphones (SA) and 38 students as a control class using a bird's guidebook (GB). The results showed the classification ability of SA students $(\mathrm{N}$-gain $=0$ $.54)$, and GB $(\mathrm{N}$-gain $=0.44)$ showed a significant increase in the medium category. The parametric test using a t-test $(\mathrm{p}$-value $=.038$ ) showed a significant difference between SA and GB. Thus it can be concluded that technological progress can be used in learning if it is well designed. Implications of smartphone applications can develop in future learning, of course, must be designed according to needs.
\end{abstract}

Keywords-i-Bird application, classification skills, learning innovation, birds, zoology vertebrate.

\section{Introduction}

\subsection{Mobile learning}

The rapid development of technology affects all aspects of life, especially in the field of education. The influence of technological advances in education must be immediately addressed wisely and think about how technology adopted in the field of education. The technology so far developed is a technology that uses cellular devices known as mobile learning. Research on mobile learning is becoming a trend at the 
moment, quite effectively applied in learning. Mobile learning helps improve methods and quality of effective learning to improve student achievement $[1,2]$. With mobile learning, it allows students to obtain their knowledge independently, more effectively, and efficiently, and gives satisfaction to students because they can access knowledge anywhere and anytime $[3,4]$.

Mobile learning seems like an innovative learning method for implications for the goals to be achieved. However, we need to think about how to design learning using mobile learning, which will have positive implications for learning outcomes. The use of mobile learning that designed appropriately will provide effectiveness in learning [5]. Teachers, in this case, as the spearhead of learning success, must have the competence to develop and design methods by implementing mobile learning. Learning by using mobile learning has practical implications for teachers in preparing for professional learning throughout [6]. Using mobile learning is very useful, especially for students as learning targets. Teachers must be able to design so that mobile learning provides convenience in learning activities. The application of mobile learning must provide satisfaction for users who get direct feedback in the learning process to improve methods and efficiency in learning [7]. Thus, the need for the development of innovations that integrated into the learning curriculum. In line with the opinion [8] and [9] states that curriculum innovation can develop by integrating technology, this will have positive implications in the future. Of course, curriculum development that integrates previous technology must go through an analysis of needs in learning, adjustments to the conditions of facilities, and infrastructure that support learning.

The application of mobile learning can help students have a scientific basis, independent learning, facilitate learning models, and develop high-level skills that support lifelong learning $[10,11]$. One of them is a smartphone device that has the potential to provide more meaningful learning opportunities and increase student involvement and will provide opportunities for learning anywhere, changing lifelong learning patterns can shape student learning behavior $[12,13,14]$. The application of mobile learning certainly cannot be separated from the pedagogical aspects, because this is important in addition to achieving goals in learning. Teachers must have the ability to take into account pedagogical aspects by designing learning desks that focus on integrating mobile technology using mobile devices in learning [15]. Several studies have revealed that with the right design, the application of mobile learning is very effective than those who do not use mobile learning. Mobile learning encourages students' conceptions into the reproduction, transition, and construction of the resulting knowledge [16]. Students using mobile learning are more satisfied than those who do not have it, increased learning outcomes, and lower cognitive load of students [17].

The application of mobile learning is not as easy as predicted. Some obstacles will become obstacles, especially in Indonesia, because there not evenly distributed facilities and infrastructure that support education in implementing online learning. The use of mobile learning is, of course, using cellular devices that are supported, supported by compatible network devices. Things that often-become obstacles in the application of mobile learning are technology, students, pedagogical conditions, and facilities that support online learning [18]. Mobile technology plays an important role in the academic life of students. Digital devices can connect users to the world directly, in- 
crease accessibility to information and enable users to interact with each other, improve student achievement so that it can adopt in pedagogical methods of learning $[19,20]$. Although, at present, there is no ideal method for implementing mobile learning in the short term [21]. Besides, teacher attitudes and teacher competencies must be qualified to adopt mobile learning to provide convenience in using it [22]. Another obstacle comes from students' parents. They must understand the technological development implemented in learning. In this case, parents must have a positive attitude toward learning that uses mobile learning [23]. The teacher should be a serious concern on how to implement mobile learning by overcoming obstacles that might become obstacles in its implementation. Although learning to use mobile learning is a necessity at this time to welcome the era of industry 4.0 , but we must be able to understand and analyze the possible obstacles that will occur.

\subsection{Smartphone application}

The rapid development of smartphone applications on several supporting features continues to grow from year to year. Many of the applications developed used to support the learning process. Still, many applications are only entertainment for users can installing via a mobile device that owned. Technological advances can felt quickly, one of which is smartphone technology. At this time, the majority of people own and use smartphones in their daily lives. However, smartphones are more widely used for social purposes, games, listening to music rather than being used to support the learning process. It is difficult to avoid the development of smartphones with increasingly sophisticated features, while we know the effects of smartphones on society and the environment [24]. The many applications contained in smartphones only used as a means of entertainment and social media. Most students have a smartphone, but only a small proportion uses it in the learning process. Smartphone applications are more widely used as a tool for social interaction, games (games) and entertainment [25], more useful if the smartphone application used to support the learning process of course with the right design [26,27,71]. At this time, the development of some smartphone applications is not supported by relevant features for use in the learning process. Only a few features. For this reason, it is necessary to develop relevant cellular applications to be used to support the learning process. Many things we can do one of them with visualization; this is quite effective to increase student motivation and learning interest. Besides, students can develop visual learning content with their creations [28].

Currently, not a reason that at this time, learning to use a smartphone application is difficult to do. Smartphones are no longer a difficult tool to come by. All students almost have them today. The smartphone is one of the most commonly used devices and accessed by people all over the world. Various smartphone applications are developed with various platforms to meet the needs of users, especially to improve the learning process that is fast and effective $[29,30]$. The affordability of the use of mobile technology can increase the acceleration of learning. Provide ease in data collection, analysis, and presentation so that it can encourage collaboration and enhance interaction between students to conduct discussions and will create new meanings and 
understandings in learning as part of the scientific learning process [31, 32, 33]. This potential can use as a means to support the learning process in a better direction. learning is not only done in the classroom. Mobile devices have great potential to be developed in supporting learning inside and outside the classroom, such as laptops, smartphones, digital assistants, of course, by considering several aspects in integrating them [34,24]. The mobile device, of course, will be a learning innovation if the development of smartphone technology can designing appropriately.

Using smartphone applications in supporting learning has many advantages in the learning process. Learning by using a smartphone application is not limited by space and time, not limited to the classroom. So that it can provide flexibility for students to explore their knowledge more broadly, if specifically developed, it can help improve learning practices and provide further opportunities to build connections, foster collaboration between students and lecturers [19,32]. The implementation of smartphones in learning provides more benefits than learning with traditional methods. Students will be more involved and motivate students to learn. Many smartphone applications developed to increase self-confidence, finding, and discovering new concepts. Learning will be more student-centered by incorporating smartphone applications in learning and will have a positive impact that can affect student learning $[35,36,37]$. By integrating smartphone applications, students gain new experiences in learning. But what often happens at this time, smartphone ownership is not widely used to support learning, of course, worrying where applications that often used are entertainment and social media applications.

The use of smartphone applications in learning, of course, must be designed with clear instructions. the teacher as a facilitator must guide students in using the application in learning. With proper guidance and instruction to students, the use of smartphones in learning will be more interesting and can improve cognitive abilities and student involvement in learning $[38,39,40]$. With proper guidance, many benefits will gain in the learning process. Students will learn independently to explore the material they need to support learning freely. The use of new technology will encourage exploration of effectiveness and collaborative learning in various fields of science [41]. Thus, many benefits will be obtained if the smartphone application can develop to support the learning process. Other uses of technology-based smartphone applications can increase collaboration between groups, add new experiences, lead to constructivist learning, and help improve collaborative student learning [33,36]. At this time, many mobile devices are adopted and used by many groups and proven to exert influence. In everyday life, aside from personal use, smartphones widely used to find information and references in relevant learning $[42,43,44]$. Many things can be done by students to get the knowledge they need. Smartphones provide unlimited access, making it easier for students to find something they need. Learning by using a smartphone device will increase student mobility and enable authentic learning with the help of several features such as social media, videos, micro-blogs, photos, interactive wallpaper modules, and other devices. That can support the learning process $[32,41]$, helping students to improve their abilities digital literacy and increase learning motivation and independent learning [45]. It can be used for distance learning and raising awareness among students to learn [46,47]. 


\subsection{Student's beliefs and attitude}

Smartphone applications that developed must provide confidence to students that the applications they will use must be able to support learning needs. The smartphone applications, of course, difficult to develop. Therefore, before we have to analyze the learning needs of students, the application developed will be useful and following their needs. The technology developed must be easy to use with a clear design and usage guidelines, so students are easy and understand how to use it. Applications developed must be able to increase student involvement in learning. Mobile technology can develop to help students access information better, engage in scientific research, and can improve group performance, and can foster a positive attitude $[48,49]$. Developing mobile technology is certainly not easy. In addition to the developed application that must be relevant to the needs of students, we also have to think about students' attitudes and learning styles.

Applications developed must encourage learning motivation, so students are happy to use it. It is important because a strong application, of course, will indirectly shape the character of students in an awareness of learning. The use of smartphone applications among students indirectly will build self-regulation and self-efficacy of students so that they will realize the importance of learning [50,51]. Students need to have selfregulation in learning. They will be able to regulate themselves, influence their behavior by regulating the environment, creating cognitive support, and carrying out consequences for their behavior. Self-regulation is the ability to regulate one's behavior and one of the main drivers of human personality. Achieve an optimal goal, and a person must be able to set his behavior, directing the behavior to achieve the desired goals. Self-efficacy is related to self-confidence to have the ability to take the expected action. Self-efficacy is a self-assessment, whether it can do good or bad actions, right or wrong, can or cannot do as required. It is what expected after students learn to use a smartphone application.

Conventional learning will have a saturated effect on students. By using a smartphone application, it hoped that students would have the will to learn even more enthusiasm. It is not be done for many teachers in Indonesia. The smartphone application not used maximally to support the learning process. By using the smartphone application of students in learning activities will be increased, they will be directly involved so that it can increase student motivation. Therefore, the curriculum needs to be developed by incorporating elements of technology $[52,53]$. It is necessary to think about how this technological advancement can be utilized maximally in education. Cellular technology integration needs to develop in the school syllabus and curriculum. Of course, by choosing and designing an appropriate application to minimize the level of abuse. There are thousands of applications available today, choosing the most appropriate education for students is difficult and problematic for teachers and educators [54]. Many factors of the difficulty of applying smartphone applications to support the learning process include the relevance of the applications used, the teacher's competence in using applications, and supporting facilities at school.

Learning to use a smartphone application is quite practical compared to using a computer or laptop. In the 21 st century learning, rapid technological advances result- 
ed in the smartphone revolution being multifunctional, easier to use, and compatible to help solve student work so that there were many positive impacts $[55,56]$. Learning with a smartphone can be done anywhere, and at any time, so the results will be better than using a laptop or computer that is considered less practical. Using mobile devices in learning is better than using computers. Smartphones can apply to various ages, various methods, various instructions, and various subject domains. So that they can broaden student knowledge and can use as a source of learning [57]. Building harmonious collaboration between groups, increasing collaboration between teachers and parents [58], so that the learning process will be faster, more effective, and more interactive [59]. Students feel their involvement by using applications, has increased their competence. They acquire relational and communicative skills when they collaborate in teams. On the other hand, some students do not feel the benefits and ease of use of educational applications on their mobile devices [60]. Thus, the developed application must give confidence to the students as far as the learning is quite effective compared to traditional methods. Building students' beliefs and attitudes in using applications is certainly a difficult thing, and we need to think about it in the future.

\subsection{Classification skills using smartphone}

Indonesia is one of the mega-biodiversity countries that have a high level of biodiversity. Facilitate the study of the diversity of living things, and a good classification ability is needed. The ability of classification, in particular to group species based on their characteristics, needed at this time as one of the capabilities that support the lectures in Vertebrate Zoology. Good classification skills will always support lectures. The ability of classification is essential and should apply as well as at the university because this is important to train students to group species. At this time, training in the ability to classify species easily done with the help of mobile devices with a variety of applications. Many new methods and approaches can use to improve classification capabilities; one of them is using smartphone software [61,62]. Thus, practicing the classification ability of students not using traditional methods can be assisted with technology, in this case, cellular technology. Many smartphone applications have developed that can use to identify species of both animals and plants. Several applications have developed to help the identification process of which species are grouped [63]. Before having the ability to group species, students must go through the process of identification first. It shows that identification skills are needed to practice classification skills.

The identification ability is the basis for the grouping of living things not apply in education. So there is a lot of decline in the level of biodiversity, especially in Indonesia. Of course, this is detrimental, because, in the future, students will have to answer the challenge of biodiversity loss. Serious efforts must make immediately to overcome this, one of them is by developing various special studies to record endangered species, of course, with the help of modern technology to facilitate the classification process. Many studies have developed tools that can help practically to group species [64], with the aim of recording and conserving biodiversity [65]. The decline in species population in each country is, of course, a serious problem. Habitat loss caused 
by development that requires extensive land, including forest areas. It will affect the decline in the number of species. Thus students must understand the effects of environmental damage on animal conditions. By practicing the ability to classify species at least, provide students with the knowledge to be able to maintain biodiversity around their homes.

Many human activities are detrimental to the environment. Humans do not take into account the effects on the environment in meeting their needs. For this reason, learning should lead students to have empathy for species that needed in the future. Instilling caring attitudes towards species is not easy for students. By practicing classification skills, it hoped that students would indirectly have an awareness of the importance of preserving biodiversity with the data they obtain directly from the field. Preserving species by grouping them based on data is one of the substantial efforts that can be made at this time [66], with the right method the level of biodiversity will always be maintained [67]. Armed technological advances, it is possible to make it easier to collect data to be grouped. Advances in technology must utilize to improve the ability of classification $[68,69]$. An important step in the classification process is to have clear targets with logical and relevant goals in the future [70,72]. Ecological progress can drive by high classification capabilities [72]. Classification capabilities can explore by utilizing technological advances, one of which is using the internet contained in the smartphone application. Thus, to practice the classification ability of students, of course, requires the right method and the support of tools in the form of sophisticated technology to facilitate the work. Many cellular applications that have developed can use as the right tools according to the needs; of course, they have to go through continuous trials. In this study, practicing the ability to group species specifically for the Aves class is one of the materials in the Vertebrate Zoology lectures. Aves will specifically record in the West Java region. The reason is that West Java has the potential diversity of classes that are interesting to study. In West Java, there are 467 bird species and 64 species, including endemic birds [74]. Based on the problems previously described, this study aims to improve the classification ability of Biology teacher candidates by using the i-Bird application. This research involved students at FKIP Universitas Pasundan Bandung in the lecture of Zoology Vertebrate. The importance of the classification capabilities possessed by students in Zoology Vertebrate lectures is to support their ability to classify the data they have obtained from the field. In the long run, students will have an awareness of the importance of the existence of species around their homes.

\section{$2 \quad$ Method}

\subsection{Research design}

This study uses a quasi-experimental method with a randomized control group pretest-posttest design. Involves as many as 82 prospective biology teacher students who participated in this study. Students are divided into two groups, as many as 44 students joined in the experimental group using the i-Bird application on smartphones 
(SA). As many as 38 students joined the control group using the bird's guidebook (GB). Aves data collection carried out during field lecture activities. Data collection capabilities of classification through written tests.

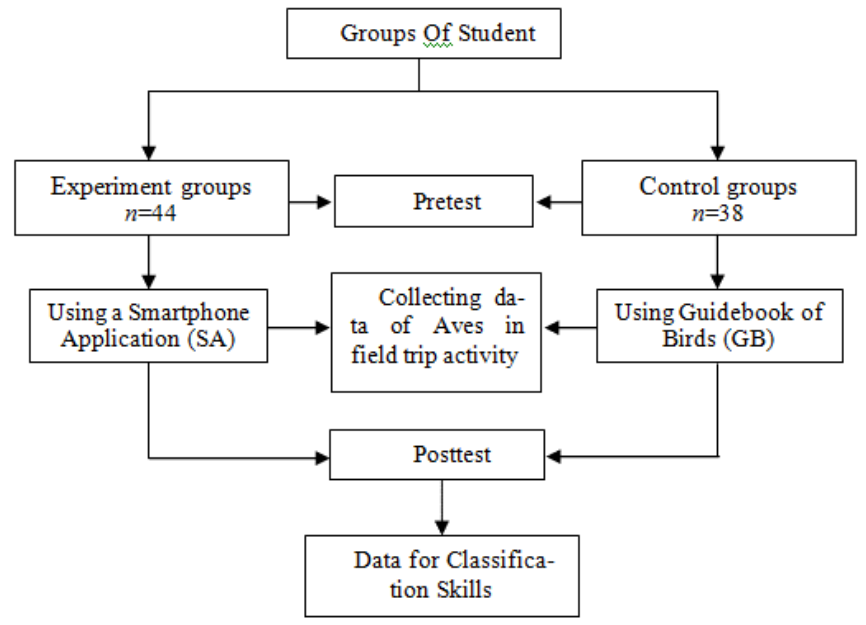

Fig. 1. Research Design

\section{2 i-Bird application}

This application specially designs for studying class, Aves. This application can be used by students to classify birds based on the knowledge they have. This application uniquely creates for Android users' version 4.0.3 and above. The database automatically saves in the Firebase product on Google. The programming language uses JAVA. The Android SDK used to create this application is Android SDK 4.0.3. (Ice Cream Sandwich). This application is online; in the beginning. The form used to download data from cloud storage online automatically. This application will automatically update the data along with upgrading the android version. The application developed contains the contents of various class Aves found in West Java. In learning, students can take pictures with their cell-phone cameras, create images, and describe views to facilitate grouping. The results of student work will be stored in a database automatically. 


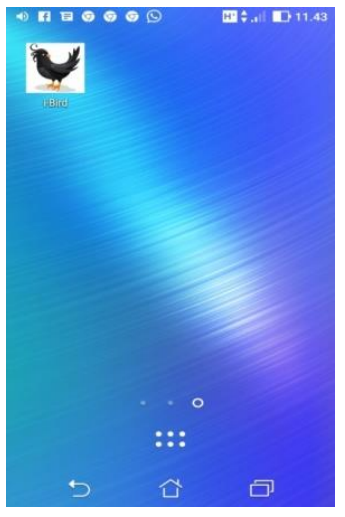

a)

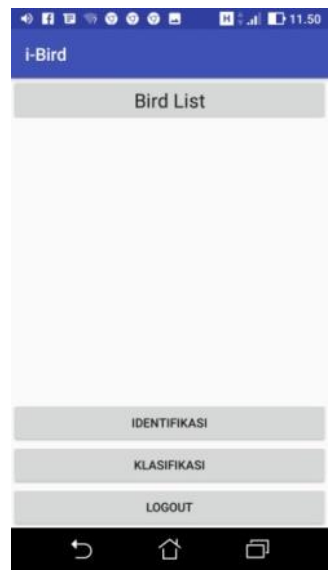

d)

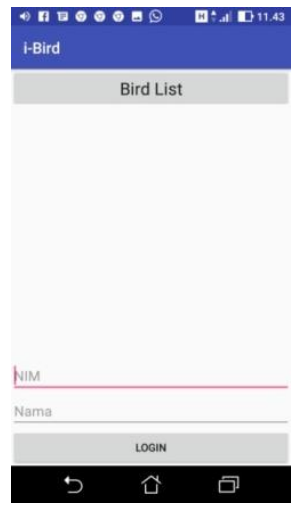

b)

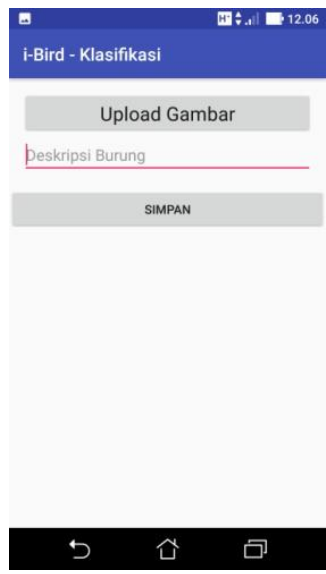

e)

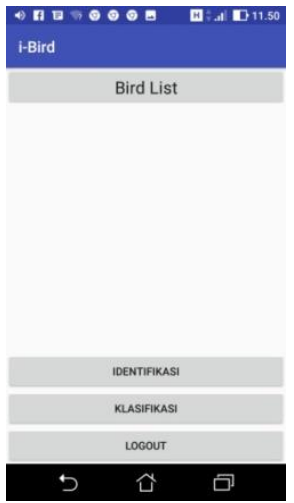

c)

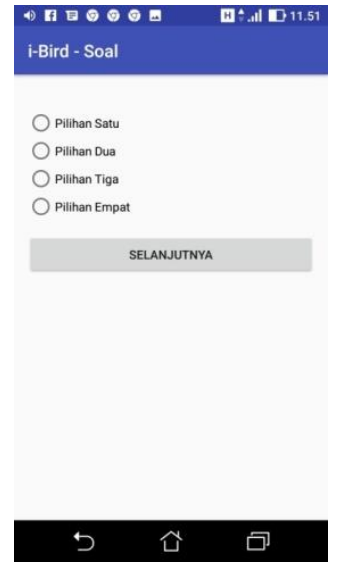

f)

Fig. 2. Flow prototype i-Bird application; A. Home screen i-Bird application. B. Display for login by entering NIM and Name. C. Display of tasks, if click Classification, then appears in picture D, D. Display classification tool. If you click classification morphology, go to figure $\mathrm{E}$ if you click the question enters the picture F, E. Views for uploading birds and morphological descriptions if birds successfully upload. They can be identified based on their morphology (head, body, wings, legs, and tail); F. Display for working on questions, classification skills in multiple-choice forms.

\subsection{Classification skills indicators}

Some indicators of student classification ability developed into several signs. This indicator can use to measure the classification ability of students. 
Table 1. Indicators of Classification Skills

\begin{tabular}{|c|l|}
\hline Indicators & \multicolumn{1}{c|}{ Student competence } \\
\hline Analyze & $\begin{array}{l}\text { Able to look for species differences based on their morphological character- } \\
\text { istics } \\
\text { Ready to search for species similarities based on their morphological charac- } \\
\text { teristics }\end{array}$ \\
\hline Classify & $\begin{array}{l}\text { Able to determine the criteria for each species based on the morphology } \\
\text { Able to group species based on their criteria } \\
\text { Ready to arrange groupings appropriately }\end{array}$ \\
\hline $\begin{array}{c}\text { Explain } \\
\text { characteristics }\end{array}$ & $\begin{array}{l}\text { Able to analyze species characteristics based on their morphology } \\
\text { Able to explain the features of each species observed }\end{array}$ \\
\hline Formulate problems & $\begin{array}{l}\text { Able to analyze species characteristics based on their morphology } \\
\text { Ready to find issues based on the phenomenon that occurs } \\
\text { Able to provide the formulating problems regarding grouping species }\end{array}$ \\
\hline Conclude & \begin{tabular}{l} 
Able to give the best conclusions \\
\hline
\end{tabular} \\
\hline
\end{tabular}

\section{$3 \quad$ Result}

Zoology Vertebrate is one of the main branches of biology that studies animals. Starting from Pisces, Amphibians, Reptiles, Aves, and Mammals. This research designed using technology in the form of an i-Bird application explicitly made to study Aves. Applications created and developed can be downloaded and installed on an Android smartphone. The application contains features to be used by students in identifying Aves they find during field lecture activities. Students can immediately take pictures that they see in the field. Furthermore, they can locate images through the iBird application to be grouped based on the knowledge they have. Some groups of students use manuals to classify Aves.

The research data captured through a pretest before learning using the i-Bird (SA) and guidebook (GB) applications, then the posttest. Before the parametric test is done, the normality test is done, the homogeneity test is a prerequisite, then the parametric test for the significance test using a paired-sample t-test. The results of data analysis of students' classification abilities presented in Figure 3. 


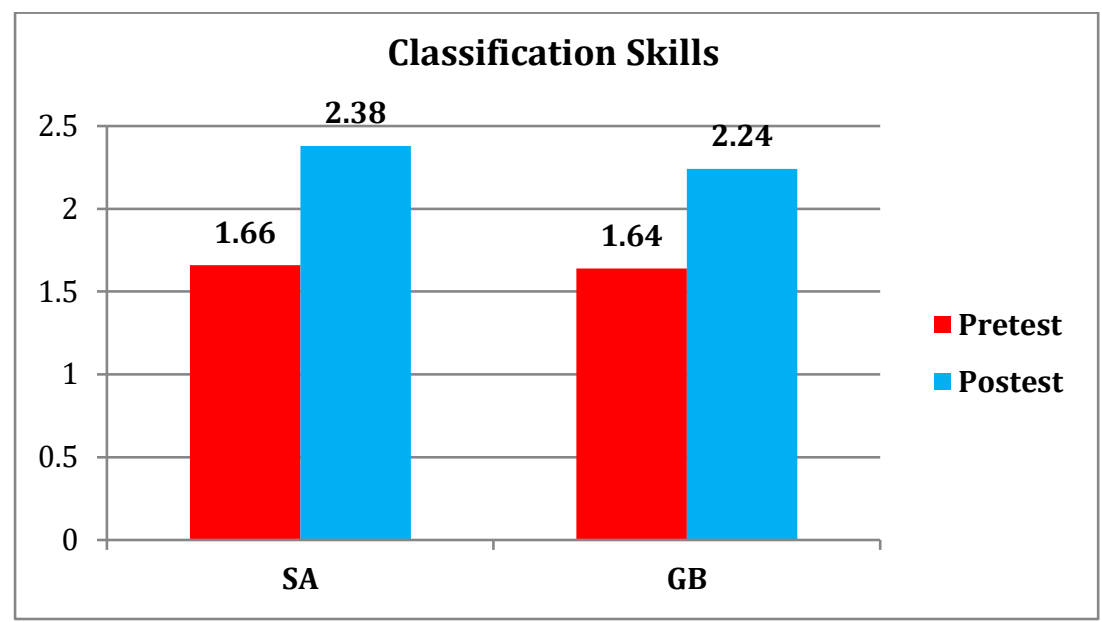

Fig. 3. The average score of pretest and posttest classification skills of SA and GB

Based on Figure 3., information obtained that the average score of the experimental class classification ability pretest using the i-Bird application (SA) is 1.66, and the pretest classification ability of the control class using manuals (GB) is 1.64 . While the average score of posttest classification ability for the experimental class (SA) using the i-Bird application was 2.38, and the posttest classification ability for the control class using the guidebook (GB) was 2.24. There was a significant increase in the experimental class (SA) compared to the control class (GB). But these results cannot be used as a guide to concluding, for the next step, it is necessary to do statistical measures.

The parametric test in this study used the paired-sample t-test. Assuming that the samples from both experimental groups $>30$. The parametric analysis carried out to test the hypothesis, the hypothesis test using the t-test performed on the pretest, and posttest data on the ability to classify students to see an increase in the ability to organize in both groups. A paired sample t-test also carried out to see whether there were differences in the ability to classify experimental classes using i-Bird applications and control classes using manuals. Data recapitulation of paired-sample t-test results for the ability to rank students in both groups presented in Table 2.

Table 2. t-test Experiment Class (SA)

\begin{tabular}{|c|c|c|c|c|c|c|c|c|}
\hline & \multicolumn{5}{|c|}{ Paired Differences } & \multirow{3}{*}{$\mathbf{t}$} & \multirow{3}{*}{ df } & \multirow{3}{*}{$\begin{array}{c}\text { Sig. } \\
\text { (2-tailed) }\end{array}$} \\
\hline & \multirow[t]{2}{*}{ Mean } & \multirow[t]{2}{*}{$\begin{array}{c}\text { Std. } \\
\text { Deviation }\end{array}$} & \multirow[t]{2}{*}{$\begin{array}{c}\text { Std. Error } \\
\text { Mean }\end{array}$} & \multicolumn{2}{|c|}{$\begin{array}{l}95 \% \text { Confidence } \\
\text { Interval of the } \\
\text { Difference }\end{array}$} & & & \\
\hline & & & & Lower & Upper & & & \\
\hline $\begin{array}{l}\text { Pair 1 } \\
\text { pretest_SA - } \\
\text { posttest_SA }\end{array}$ & -.7136 & .4278 & .06450 & -.84372 & -.58355 & -11.064 & 43 & .000 \\
\hline
\end{tabular}


Based on Table 2. shows that the p-value at $\alpha=0.05$ is 0.000 . Thus the $p$-value of $0.000<0.005$. Therefore, $\mathrm{H} 0$ is rejected, meaning that there is a significant increase in the ability to classify in the experimental class using the i-Bird application. Subsequent data analysis performed paired-sample t-tests for the control class. Data recapitulation of the results. The analysis of the ability to classify students in the control class presented in Table 3 .

Table 3. t-test Control Class (GB)

\begin{tabular}{|c|c|c|c|c|c|c|c|c|}
\hline & \multicolumn{5}{|c|}{ Paired Differences } & \multirow{3}{*}{$\mathbf{t}$} & \multirow{3}{*}{ df } & \multirow{3}{*}{$\underset{\text { (2-tailed) }}{\text { Sig. }}$} \\
\hline & \multirow[t]{2}{*}{ Mean } & \multirow{2}{*}{$\begin{array}{c}\text { Std. } \\
\text { Deviation }\end{array}$} & \multirow{2}{*}{$\begin{array}{c}\text { Std. } \\
\text { Error } \\
\text { Mean }\end{array}$} & \multicolumn{2}{|c|}{$\begin{array}{l}95 \% \text { Confidence Inter- } \\
\text { val of the Difference }\end{array}$} & & & \\
\hline & & & & Lower & Upper & & & \\
\hline $\begin{array}{l}\text { Pair 1 } \\
\text { pretest_GB - } \\
\text { posttest_GB }\end{array}$ & -.6052 & .44476 & .07215 & -.7514 & -.4590 & -8.38 & 37 & .000 \\
\hline
\end{tabular}

Based on Table 3. shows that the $p$-value at $\alpha=0.05$ is 0.000 . Thus the $p$-value of $0.000<0.005$. H0 rejected, meaning that there is a significant improvement in the control class by using the manual. Furthermore, paired-sample t-tests were performed on the posttest scores to see whether or not there was an ability to classify students who used the i-Bird application with students who used the guidebook-data recapitulation of the results of the analysis presented in Table 4.

Table 4. t-test Classification Skills of SA and GB

\begin{tabular}{|c|c|c|c|c|c|c|c|c|}
\hline & \multicolumn{5}{|c|}{ Paired Differences } & \multirow{3}{*}{$\mathbf{t}$} & \multirow{3}{*}{ df } & \multirow{3}{*}{$\begin{array}{c}\text { Sig. } \\
\text { (2-tailed) }\end{array}$} \\
\hline & \multirow[t]{2}{*}{ Mean } & \multirow[t]{2}{*}{$\begin{array}{c}\text { Std. } \\
\text { Deviation }\end{array}$} & \multirow[t]{2}{*}{$\begin{array}{c}\text { Std. Error } \\
\text { Mean }\end{array}$} & \multicolumn{2}{|c|}{$\begin{array}{l}\text { 95\% Confidence } \\
\text { Interval of the } \\
\text { Difference }\end{array}$} & & & \\
\hline & & & & Lower & Upper & & & \\
\hline $\begin{array}{l}\text { Pair 1 } \\
\text { posttets_SA - } \\
\text { posttest_GB }\end{array}$ & .14211 & .40778 & .06615 & .00807 & .27614 & 2.148 & 37 & .038 \\
\hline
\end{tabular}

Based on Table 4. information is obtained that the sig value ( $p$-value) at $\alpha=0.05$ is $0.038<0.05$. Thus, $\mathrm{H} 0$ is rejected, meaning that it can conclude that there is a significant difference in the ability to classify students who use the i-Bird application with students who use manuals.

Based on the analysis of $\mathrm{N}$-gain scores, the classification ability of students who use the $\mathrm{i}$-Bird application with an $\mathrm{N}$-gain score of 0.54 included in the medium category. It shows that the increase in the classification ability of students who use the iBird application increases significantly with a moderate increase. Analysis of the Ngain score on the classification ability of students who use the guidebook with an $\mathrm{N}$ gain score of 0.44 included in the medium category. It shows that the increase in the classification ability of students who use guidebooks increases significantly with a moderate increase. 


\section{Discussion}

Content development in applications certainly has advantages and disadvantages. Applications developed in this study still need to be developed and refined. The results of this study can use as a reference for future lecture programs in different fields and scopes. Based on the results of this study, we can assume that advances in information technology, especially smartphones, can integrate into learning. Thus it is necessary to design and develop a special curriculum in which integrated information technology in meeting the learning needs of the 21 st century, industrial era 4.0, and human society 5.0. With an appropriate program under the needs, kana provide effectiveness in learning. The diversity of living creatures in the world is very abundant, especially class Aces. Indonesia is a mega-biodiversity country that has a high level of diversity in the world. This study focuses on the diversity of Aves classes found in West Java, according to data recorded in [75] West Java Province has a high potential of Aves diversity as many as 467 species and as many as 64 species including endemic. Abundant species diversity will be difficult to study if it does not have good classification skills. A good classification ability will always have the ability to group species based on certain characteristics and criteria.

This study focuses on developing smartphone applications, i-Bird applications that use to improve the ability to classify prospective biology teacher students in the study of Zoology Vertebrate. Based on Figure 3. shows an increase in both groups. Based on the results of the N-Gain analysis, the classification ability of students who use the i-Bird application $(\mathrm{N}$-gain $=0.54)$ and students who use a guidebook $(\mathrm{N}$-gain $=0.44)$ significantly increases with the medium category. Furthermore, the significance test was done through the t-test, based on Table 4, there was a significant difference between students who used the i-Bird application and students who used the guidebook ( $\mathrm{p}$-Value $=0.038)$. With the results of this research can be obtained information that the ability of classification can improve by integrating the use of technology that design and used appropriately to support learning. [69] states that classification capabilities can explore by utilizing technological advances, one of which is using the internet contained in smartphone applications. In line with this, [62] states that various methods can use to improve the ability of classification with the help of software.

The ability to classify in this study assisted by the design of special applications in i-Bird. Applications are designed according to learning objectives and adjusted for indicators of ability to classify. The classification mechanism of the Aves class by students can see in Figure 4. 


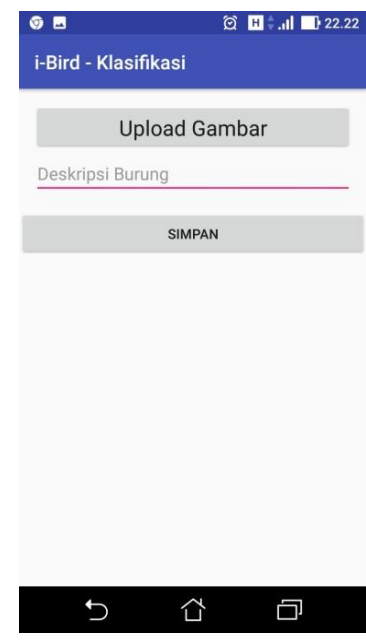

a) Form to classify, upload a picture

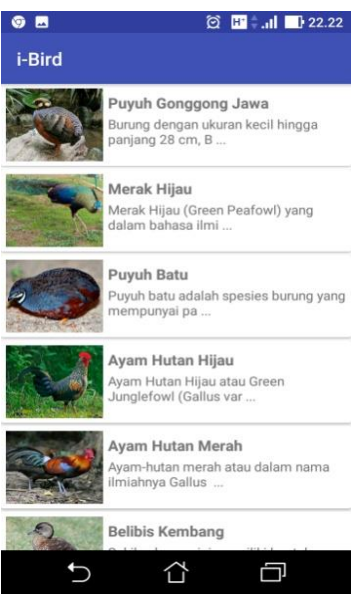

d) Stored in the database

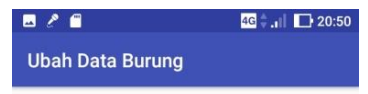

Ayam Hutan Merah

Gallus gallus

Galliformes

Phasianidae

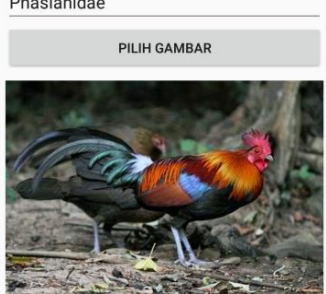

Ayam-hutan merah atau dalam nama

○

b) Giving names and grouping based on orders, family, and naming
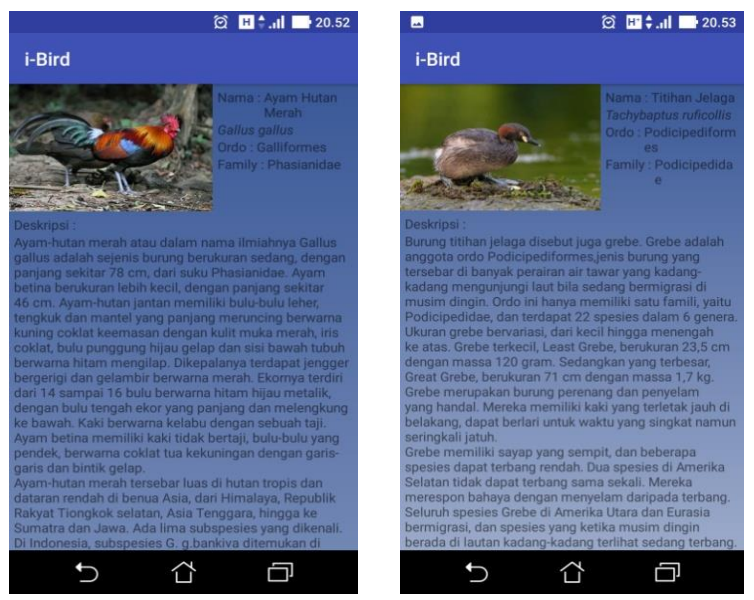

e) Can be accessed through a bird list in the database

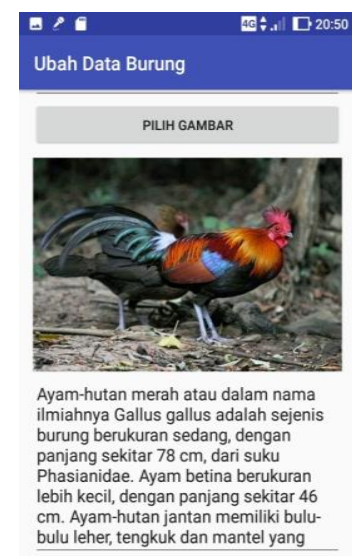

\section{$\supset$ 仓ิ}

口

c) Writing the description
A) Another example
of a database

Fig. 4. Aves Classification Process on i-Bird Applications by Students 
Figure 4. shows the classification process carried out by students on their respective smartphones. After the student analyzes the photos taken with a camera, the images are uploaded and grouped according to the results of the morphological characteristics analysis (Figure 4.B). this is in accordance with the classifying indicator that is analyzing and classifying. Furthermore, with the form provided, students provide a description related to the results of analysis and photo observations (Figure 4.C). this trains students to explain characteristics based on observations. After the process is complete, the classification results will be automatically stored in the database (Figure 4.D) and can be accessed at any time. The i-Bird application helps students classify Aves classes based on their morphological characteristics. With the i-Bird application, the classification process will be more effective and faster. In line with this, [65] states that technology can be used to support grouping of species effectively and takes less time than manually. The findings of this study indicate that the i-Bird application used in learning can improve the ability to classify students.

The development of digital technology at this time provides support and convenience for designing methods or approaches in learning. Teachers should develop innovative methods with technology integration and should reduce traditional methods. The findings of this study can be used as a reference that learning can be done by utilizing current developing technologies, for example smartphone technology of course with the right method. [61] states that new methods can be designed harmonized with technological developments to practice classification skills. Agreeing with that, [63] adding that grouping of species is an estuary of identification, the identification process can be helped by applications that have been widely developed. We cannot deny that technological progress has influenced almost all elements of education. The big influence can be seen with changes in student learning styles. In today's world, most students have software such as laptops and smartphones equipped with advanced features. But the existence of these technological tools is not used entirely for learning. [25] states that smartphones are more widely used for social interaction, playing games and listening / playing music rather than being used for learning. [56] suggested that smartphones that are supported with increasingly sophisticated features are often misused.

The role of technology should be maximized in learning [73]. The classification process will certainly be easier with the help of technology especially those contained in smartphone applications. The ease of studying species classification at this time many tools such as software that has been developed. [64] the development of practical aids has been carried out with the aim of assisting grouping of species. [65] species classification is indispensable for conservation efforts, therefore special skills are needed to develop classification abilities. [66] added a database needed to classify species as conservation efforts. The right method is of course needed how species can be grouped appropriately. [67] biodiversity will be maintained by using appropriate methods to categorize it. In line with this, [68] states that technological progress must be maximally utilized as a method or approach to improve classification capabilities. An important step in the classification process is to have clear targets with logical and relevant goals in the future [70] ecological progress can be driven by high classification capabilities [72]. Thus it is clear that the ability to classify is very necessary and 
possessed by students, especially prospective biology teacher students in an effort to facilitate the study of living things. With the support of technological advances surely approaches and various methods can be better developed.

\section{Conclusion}

The rapid development of cellular technology must be maximized in supporting learning. The advanced features contained in the smartphone application can be developed to assist students in learning. A specially designed smartphone application will make it easy for students to find new knowledge. In this study, the application developed in the form of the i-Bird application is specifically used to study Aves in order to practice the classification skills of prospective Biology teacher students. Classification skills are very important possessed by students so that they can help them facilitate learning of various species. The ability of classification is needed, especially to classify very large numbers of species. By integrating technology, students' classification abilities can be improved. The results of this study indicate that the use of technology appropriately can help prospective biology teacher students improve their classification skills. This has positive implications in the future, how technology can be designed and implemented in the learning process with specific goals and needs. In addition, the results of this study can be used as a reference in the future with more sophisticated development. Applications that are designed still require the addition of features such as video storage and the addition of a larger data storage capacity.

\section{Acknowledgement}

This research was fully funded by a BPPDN scholarship. Acknowledgments also the authors convey to all prospective biology teacher students at FKIP Pasundan University who have helped a lot in carrying out this research.

\section{$7 \quad$ References}

[1] Zhang, X. \& Bi, J. (2018). Design of a College English Mobile Learning System Based on CAD Model Research Background of Mobile Learning. iJET. 13(4): 139-49. https://doi. org/10.3991/ijet.v13i04.8477.

[2] Ningsih, S. \& Adesti, A. (2020). Android-Based Mobile Learning: Its Effect on Students' Learning Achievement. Advances in Social Science, Education and Humanities Research, volume 422 (Icope 2019): 100-103. https://doi.org/10.2991/assehr.k.200323.099

[3] Chung, Ching-jung, Gwo-jen Hwang, \& Chiu-lin Lai. (2019). Computers \& Education A Review of Experimental Mobile Learning Research in 2010 - 2016 Based on the Activity Theory Framework. Computers \& Education 129(July 2017): 1-13. https://doi.org/10.101 6/j.compedu.2018.10.010.

[4] Guerrero, M. A. H., Garcia, A. C., Dominguez, E. L., Velazquez, Y. H., Nieto, M. A. M., Calleja, J. D. \& Isidro, S. D. (2020). SiGOAM : Web System for Developing Quality Mo- 
bile Learning Objects. Comput Appl Eng Educ. 2020;1-22. https://doi.org/10.1002/cae. 22201.

[5] Suartama, K. I., Setyosari, Punaji, \& Ulfa. (2019). Development of an Instructional Design Model for Mobile Blended Learning in Higher Education. iJET. Vol. 14, No. 16, 2019, 422. https://doi.org/10.3991/ijet.v14i16.10633

[6] Matthew, K. \& Maher, D. (2019). Mobile Learning in Pre-Service Teacher Education : Examining the Use of Professional Learning Networks. Australasian Journal of Educational Technology. 35(1): 135-48. https://doi.org/10.14742/ajet.4073

[7] Liu, L., Zhang, L., Ye, P. \& Liu, Q. (2018). Influence Factors of Satisfaction with Mobile Learning APP : An Empirical Analysis of China. iJET. 13(3): 87-99. https://doi.org/10.39 91/ijet.v13i03.8381

[8] Looi, C. K., Sun, D., Wu, L., Seow, P., Chia, G., Wong, L. H., ... Norris, C. (2014). Implementing mobile learning curricula in a grade level: Empirical study of learning effectiveness at scale. Computers and Education, 77, 101-115. https://doi.org/10.1016/j.comp edu.2014.04.011

[9] Edwards, R. (2015). Software and the hidden curriculum in digital education. Pedagogy, Culture \& Society, 23(2),(2015), 265-279. http://doi.org/10.1080/14681366.2014.977809.

[10] Zhang, Y. \& Zuo, L. (2019). College English Teaching Status and Individualized Teaching Design in The Context of Mobile Learning. iJET. Vol. 14, No. 12, 2019, 85-96. https:// doi.org/10.3991/ijet.v14i12.10704.

[11] Hwang, Gwo-jen, \& Qing-ke Fu. (2020). Advancement and Research Trends of Smart Learning Environments in the Mobile Era. Int. J. Mobile Learning and Organisation, Vol. 14, No. 1, 2020. https://doi.org/10.1504/ijmlo.2020.10024691

[12] O'Bannon, B. W., \& Thomas, K. (2014). Teacher perceptions of using mobile phones in the classroom: Age matters! Computers and Education, 74, 15-25. https://doi.org/10.1016/ j.compedu.2014.01.006

[13] Joynes, V. \& Fuller, R. (2015). Legitimisation, personalisation and maturation: Using the experiences of a compulsory mobile curriculum to reconceptualise mobile learning. Medical Teacher, https://doi.org/10.3109/0142159x.2015.1075651.

[14] Kim, Y., \& Smith, D. (2015). Pedagogical and technological augmentation of mobile learning for young children interactive learning environments. Interactive Learning Environments, https://doi.org/10.1080/10494820.2015.1087411.

[15] Kalogiannakis, M. \& Papadakis, S. (2019) 'Evaluating pre-service kindergarten teachers' intention to adopt and use tablets into teaching practice for natural sciences'. Int. J. Mobile Learning and Organisation, Vol. 13, No. 1, pp.113-127. https://doi.org/10.1504/ijmlo.20 $\underline{19.10016617}$

[16] Lin, X. F., Deng, C., Hu, Q \& Tsai C-C. (2019). Chinese Undergraduate Students Perceptions of Mobile Learning: Conceptions, Learning Profiles, and Approaches. J Comput Assist Learn. 2019;1-17. https://doi.org/10.1111/jcal.12333

[17] Zhonggen, Yu, Zhu Ying, Yang Zhichun, \& Chen Wentao. (2018). Student Satisfaction, Learning Outcomes, and Cognitive Loads with a Mobile Learning Platform. Computer Assisted Language Learning $0(0): \quad 1-19$. https://doi.org/10.1080/ $\underline{09588221.2018 .1517093 .}$.

[18] Benali, M. \& Ally, M. (2020). Towards a Conceptual Framework Highlighting Mobile Learning Challenges. International Journal of Mobile and Blended Learning. Vol. 12(1): 51-63. https://doi.org/10.4018/ijmbl.2020010104

[19] Vázquez-Cano, E. (2014). Mobile Distance Learning with Smartphones and Apps in Higher Education. Educational Sciences: Theory \& Practice, 14(4), 1505-1520. https://doi.org/ 10.12738/estp.2014.4.2012 
[20] Briz-ponce, L., Juanes-méndez, J. A., García-peñalvo, F. J., \& Pereira, A. (2016). Effects of Mobile Learning in Medical Education : A Counterfactual Evaluation. Journal of Medical Systems. 40: 136. https://doi.org/10.1007/s10916-016-0487-4

[21] Panteli, P. \& Panaoura, A. (2020). The Effectiveness of Using Mobile Learning Methods in Geometry for Students with Different Initial Mathematical Performance. Social Education Research. V. 1(1): 1-10. https://doi.org/10.37256/ser.112020128.1-10

[22] Kalogiannakis, M. \& Papadakis, S. (2017). "Mobile Educational Applications for Children : What Educators and Parents Need to Know. Int. J. Mobile Learning and Organisation, Vol. 11, No. 3, 2017: 256-77. https://doi.org/10.1504/ijmlo.2017.085338

[23] Papadakis, Stamatios, Nikolas Zaranis, and Michail Kalogiannakis. 2019. Parental Involvement and Attitudes towards Young Greek Children' S Mobile Usage.” International Journal of Child-Computer Interaction (xxxx): 100144. https://doi.org/10.1016/j.ijcci.2019. 100144 .

[24] Gowthami, S., \& Venkatakrishnakumar, S. (2016). Impact of Smartphone : A pilot study on positive and negative effects, International Journal of Scientific Engineering and Applied Science (IJSEAS), 2(3), (2016), 473-478.

[25] Kurniawan, I. S., Tapilow, F. S. \& Hidayat, T. \& Setiawan, W. (2018). Can smartphone be used to support learning? International Conference on Mathematics and Science Education of Universitas Pendidikan Indonesia Volume 3, 2018

[26] Thomas, R. L., \& Fellowes, M. D. E. (2016). Effectiveness of mobile apps in teaching field-based identification skills. Journal of Biological Education, 9266(July), 1-8. https:// doi.org/10.1080/00219266.2016.1177573

[27] Lim, S. (2017). Mobile Documentation with Smartphone and Cloud in an Emergent Curriculum. Computers in the Schools, 34:4, 304-317, https://doi.org/10.1080/07380569.2017. 1387469

[28] Nurbekova, Z., Grinshkun, V., Aimicheva, G., Nuberkov, B. \& Tuenbaeva, K. (2020). Project-Based Learning Approach for Teaching Mobile Application Development Using Visualization Technology. iJET. 130-43. https://doi.org/10.3991/ijet.v15i08.12335

[29] Mansour, E. A. H. (2016),"Use of smartphone apps among library and information science students at South Valley University, Egypt", The Electronic Library, Vol. 34 Iss 3. https:// doi.org/10.1108/el-03-2015-0044

[30] Li, Y., Guo, A., Ling Chin, C., \& Lim, J.-H. (2016). A platform for creating Smartphone apps to enhance Chinese learning using augmented reality. Scientific Phone Apps and Mobile Devices. https://doi.org/10.1186/s41070-016-0007-4

[31] Land-zandstra, A. M., \& Snik, F. (2015). Citizen science on a smartphone : Participants , motivations and learning. Public Understanding of Science, 1-16. https://doi.org/10.1177/0 $\underline{963662515602406}$

[32] Gikas, J., \& Grant, M. M. (2013). Mobile computing devices in higher education: Student perspectives on learning with cellphones, smartphones \& social media. Internet and Higher Education, 19, 18-26. https://doi.org/10.1016/j.iheduc.2013.06.002

[33] France, D., Powell, V., Mauchline, A. L., Welsh, K., Park, J., Whalley, W. B., \& Rewhorn, S. (2016). Ability of students to recognize the relationship between using mobile apps for learning during fieldwork and the development of graduate attributes. Journal of Geography in Higher Education, 8265(March), 1-11. https://doi.org/10.1080/03098265.2016.115 $\underline{4931}$

[34] Sung, Y.-T., Chang, K.-E., \& Liu, T.-C. (2015). The Effects of Integrating Mobile Devices with Teaching and Learning on Students' Learning Performance: A Meta-Analysis and Research Synthesis. Computers \& Education, 94, 252-275. https://doi.org/10.1016/j.comp edu.2015.11.008 
[35] Shih, B.-Y., Chen, C.-Y., \& Chen, Z.-S. (2006). An Empirical Study of an Internet Marketing Strategy for Search Engine Optimization. Human Factors and Ergonomics in Manufacturing, 16(1), 61-81. https://doi.org/10.1002/hfm

[36] Jong, M. S., \& Tsai, C. (2016). Understanding the concerns of teachers about leveraging mobile technology to facilitate outdoor social inquiry learning: the EduVenture experience. Interactive Learning Environments, 24:2, 328-344, https://doi.org/10.1080/10494820.2015. 1113710

[37] Clayton, K., \& Murphy, A. (2016). Smartphone Apps in Education: Students Create Videos to Teach Smartphone Use as Tool for Learning. Journal of Media Literacy Education, 8(2), 99-109.

[38] Ray, A. B. \& Deb, S. (2016). Smartphone Based Virtual Reality Systems in Classroom Teaching -a study on the effects of learning outcome. 8th International Conference on Technology for Education, 2016 IEEE, (978), 68-71. https://doi.org/10.1109/T4E.2016.21

[39] Sahlin, J. S., Tsertsidis, A., \& Islam, M. S. (2016). Usages and impacts of the integration of information and communication technologies (ICTs ) in elementary classrooms : case study of Swedish municipality schools. Learning Environments, https://doi.org/10.1080/ 10494820.2016 .1170045

[40] Tao, Z., Lai, I. K., \& Chau, K. (2018). A Research on the effect of Smartphone Use, Student engagement and Self-Directed Learning on Individual Impact: China Empirical Study. 2018 International Symposium on Educational Technology (ISET), 221-225. https ://doi.org/10.1109/ISET.2018.00056

[41] Liu R. F, Wang, F. Y., Yen, H., Sun, P. L. \& Yang, C. H. (2018). A new mobile learning module using smartphone wallpapers in identification of medical fungi for medical students and residents International Journal of Dermatology Vol 57 No 4 p 458-462. https ://doi.org/10.1111/ijd.13934

[42] Alqaryan, S., Alkhalifa, M., Alharbi, M., Alabaishi, S., \& Aldrees, T. (2016). Smartphones and professionalism: A cross-sectional study on interns and final-year medical students, (5), 198-202.

[43] Lai, H. (2018). Investigating older adults ' decisions to use mobile devices for learning, based on the unified theory of acceptance and use of technology. Interactive Learning Environments, 1-12. https://doi.org/10.1080/10494820.2018.1546748

[44] Zhai, X., Zhang, M. \& Li, M. (2016). One-to-one mobile technology in high school physics classrooms: Understanding its use and outcome British Journal of Educational Technology p 1-16. https://doi.org/10.1111/bjet.12539

[45] Yamamoto, N. (2016). Improvement of Group Discussion System for Active Learning Using Smartphone. 2016 10th International Conference on Innovative Mobile and Internet Services in Ubiquitous Computing, 143-148. https://doi.org/10.1109/imis.2016.75

[46] Gökçearslan, Ş., Mumcu, F. K., Haşlaman, T. \& Çevik, Y. D. (2016). Modelling smartphone addiction: The role of smartphone usage, self-regulation, general self-efficacy and cyberloafing in university students. Computers in Human Behavior Vol 63 p 639-649. https://doi.org/10.1016/j.chb.2016.05.091

[47] Mahenge, M. P. J. \& Sanga, C. (2016). ICT for e-learning in three higher education institutions in Tanzania. Knowledge Management \& E-Learning, 8(1), 200-212.

[48] Miller, T., Chandler, L., Mouttapa, M., Miller, T., Chandler, L., \& Mouttapa, M. (2015). A Needs Assessment, Development, and Formative Evaluation of a Health Promotion Smartphone Application for College Students. American Journal of Health Education, 46:4, 207-215, https://doi.org/10.1080/19325037.2015.1044138 
[49] Ahmed, S., \& Parsons, D. (2013). Abductive science inquiry using mobile devices in the classroom. Computers and Education, 63, 62-72. https://doi.org/10.1016/j.compedu.2012. $\underline{11.017}$

[50] Miyake, M., Takeuchi, K., \& Toda, Y. (2018). Variations of perspectives of junior high school students who have participated in Smartphone Summit for appropriate usage of the Internet and smartphones. Pastoral Care in Education, 36:2, 141-153, https://doi.org/10.10 $\underline{\text { 80/02643944.2018.1464592 }}$

[51] Lim, Y., Lee, Y., \& Han, S. (2016). Research on factors affecting the smartphone addiction of college students based on the GIA. Journal of the Korea Academia-Industrial cooperation Society, 17(5), 56-66. https://doi.org/10.5762/kais.2016.17.5.56

[52] Marty, P. F., Alemanne, N. D., Mendenhall, A., Maurya, M., Southerland, S. A., Sampson, V., Schellinger, J. (2013). Scientific inquiry, digital literacy, and mobile computing in informal learning environments. Learning, Media \& Technology, 38(4), 407-428. https:// doi.org/10.1080/17439884.2013.783596

[53] Chae, Y., \& Ha, Y. (2016). Effectiveness of Education Program for Core Fundamental Nursing Skills using Recording Video with Smartphone and Formative Feedback. Journal of Digital Convergence, 285-294. http://doi.org/10.14400/JDC.2016.14.6.285,

[54] Papadakis, S. \& Kalogiannakis, M. (2017). Mobile educational applications for children: what educators and parents need to know. Int. J. Mobile Learning and Organisation, Vol. 11, No. 3, 2017. https://doi.org/10.1504/ijmlo.2017.085338

[55] Ahad, A. D., \& Begawan, B. S. (2017). Smartphone Habits Among Youth : Uses and Gratification Theory. International Journal of Cyber Behavior, Psychology and Learning, 7(1), 65-75. https://doi.org/10.4018/IJCBPL.2017010105

[56] Hopkins, N., Tate, M., Sylvester, A., \& Johnstone, D. (2016). Motivations for 21st century school children to bring their own device to school. Information Systems Frontiers, (Douglas 2011), 1-13. https://doi.org/10.1007/s10796-016-9644-Z

[57] Aliaño, Á. M., María, A., Hueros, D., Aguaded, I., \& Guzmán, M. D. (2019). Mobile Learning in University Contexts Based on the Unified Theory of Acceptance and Use of Technology ( UTAUT ). Journal of New Approaches in Educational Research, 8(1), 7-17. https://doi.org/10.7821/naer.2019.1.317

[58] Thompson, B. C., Mazer, J. P., Grady, E. F., Christopher, B., Mazer, J. P. \& Grady, E. F. (2015). The Changing Nature of Parent-Teacher Communication: Mode Selection in the Smartphone Era. Communication Education, 64:2, 187-207, https://doi.org/10.1080/03634 $\underline{523.2015 .1014382}$

[59] Yamamoto, N., \& Uchida, N. (2018). Performance Evaluation of a Learning Logger System for Active Learning Using Smartphone. Advances in Network-based Information Systems. https://doi.org/10.1007/978-3-319-65521-5

[60] Camilleri, A. C. \& Camilleri, M. A. (2019). Mobile Learning via Educational Apps : An Interpretative Study. ICETT . 88-92. https://doi.org/10.1145/3337682.3337687

[61] Rosa, I. M. D., Marques, A. N. A. T., Palminha, G., Costa, H., Mascarenhas, M., Fonseca, C., \& Bernardino, J. (2016). Classification success of six machine learning algorithms in radar ornithology. Ibis (2016), 158, 28-42. https://doi.org/10.1111/ibi.12333

[62] Sladojevic, S., Arsenovic, M., Anderla, A., Culibrk, D., \& Stefanovic, D. (2016). Deep Neural Networks Based Recognition of Plant Diseases by Leaf Image Classification. Computational Intelligence and Neuroscience, 2016, Article ID 3289801, 11 pages https:// doi.org/10.1155/2016/3289801.

[63] Jim, C. Y. (2015). Greenwall classi fi cation and critical design-management assessments. Ecological Engineering, 77, 348-362. https://doi.org/10.1016/j.ecoleng.2015.01.021 
[64] Ballanti, L., Blesius, L., Hines, E., \& Kruse, B. (2016). Tree Species Classification Using Hyperspectral Imagery: A Comparison of Two Classifiers. Remote Sens. 2016, 8, 445; https://doi.org/10.3390/rs8060445

[65] Schuld, C., Franz, S., Hedel, H. J. A. Van, Moosburger, J., Maier, D., Abel, R., ... Rupp, R. (2015). International standards for neurological classification of spinal cord injury: classification skills of clinicians versus computational algorithms. Spinal Cord. (2015) 53, 324-331. https://doi.org/10.1038/sc.2014.221

[66] Kukunda, C. B., Duque-lazo, J., González-ferreiro, E., Thaden, H., \& Kleinn, C. (2018). Ensemble classi fi cation of individual Pinus crowns from multispectral satellite imagery and airborne LiDAR. Int J Appl Earth Obs Geoinformation, 65(September 2017), 12-23. https://doi.org/10.1016/j.jag.2017.09.016

[67] Landucci, F., Tichy, L., Sumberova, K. \& Chytr, M. (2015). Formalized classification of species-poor vegetation : a proposal of a consistent protocol for aquatic vegetation. Journal of Vegetation Science 26 (2015) 791-803. https://doi.org/10.1111/jvs.12277

[68] Razzak, M. I. (2015). Automatic Detection and Classification of Malarial Parasite. International Journal of Biometrics and Bioinformatics (IJBB), Volume (9) : Issue (1) : 2015, 112.

[69] Kurniawan, I. S., Tapilow, F. S. \& Hidayat, T. (2017). How can Smartphone-Based Internet Data Support Animal Ecology Fieldtrip? Journal of Physics: Conference Series, 895(1). https://doi.org/10.1088/1742-6596/895/1/012134

[70] Bom, R. A., Bouten, W., Piersma, T., Oosterbeek, K., \& Gils, J. A. Van. (2014). Optimizing acceleration-based ethograms: the use of variable-time versus fixed-time segmentation. Movement Ecology, V. 2:26. 2014. https://doi.org/10.1186/2051-3933-2-6

[71] Papadakis, S., \& Kalogiannakis, M. (2017). Using gamification for supporting an introductory programming course. the case of classcraft in a secondary education classroom. In Interactivity, Game Creation, Design, Learning, and Innovation (pp. 366-375). Springer, Cham. https://doi.org/10.1007/978-3-319-76908-0_35

[72] Schuld, C., Franz, S., Hedel, H. J. A. Van, Moosburger, J., Maier, D., Abel, R., ... Rupp, R. (2015). International standards for neurological classification of spinal cord injury: classification skills of clinicians versus computational algorithms. Spinal Cord. (2015) 53, 324-331. https://doi.org/10.1038/sc.2014.221

[73] Dorouka, P., Papadakis, S., \& Kalogiannakis, M. (2020). Tablets and apps for promoting robotics, mathematics, STEM education and literacy in early childhood education. International Journal of Mobile Learning and Organisation, 14(2), 255-274. https://doi.org/10.15 04/ijmlo.2020.10026334

[74] Resheff, Y. S., Rotics, S., Harel, R., Spiegel, O., \& Nathan, R. (2014). AcceleRater: a web application for supervised learning of behavioral modes from acceleration measurements. Movement Ecology, 2, 27. https://doi.org/10.1186/s40462-014-0027-0

[75] HBW and BirdLife International. (2018). Handbook of the Birds of the World and BirdLife International digital checklist of the birds of the world. Version 3. Available at: https://avibase.bsc-eoc.org/checklist.jsp?lang=EN\&p2=1\&list=birdlife\&synlang=\&region =IDjaba\&version=text\&lifelist=\&highlight $=0 . \&$ lang=EN\&p2=1\&list=birdlife \&synlang= $\underline{\text { \&region}=I D j a b a \& v e r s i o n=t e x t \& l i f e l i s t=\& h i g h l i g h t=0 . ~ h t t p s: / / d o i . o r g / 10.1017 / s 09592709 ~}$ $\underline{01211071}$ 


\section{Authors}

Iwan Setia Kurniawan, as a lecturer in the Department of Biology Education at Universitas Pasundan, Bandung, Indonesia. Develop various innovations in learning biology, in particular, developing smartphone applications to support learning.

Fransisca Sudargo Tapilouw, as a lecturer, majoring in Biology Education at Universitas Pendidikan Indonesia in Bandung. Fields of study are in the form of Zoology Vertebrate and Evolution.

Topik Hidayat as a lecturer majoring in Biology Education at Universitas Pendidikan Indonesia in Bandung. The field of science that explore in the form of Biotechnology

Wawan Setiawan, as a lecturer majoring in Computer Science Education at Universitas Pendidikan Indonesia, Bandung. The field of Science explores in the form of computer development in learning.

Article submitted 2020-02-04. Resubmitted 2020-05-12. Final acceptance 2020-05-13. Final version published as submitted by the authors. 